\title{
Richard Nötstaller verstorben
}

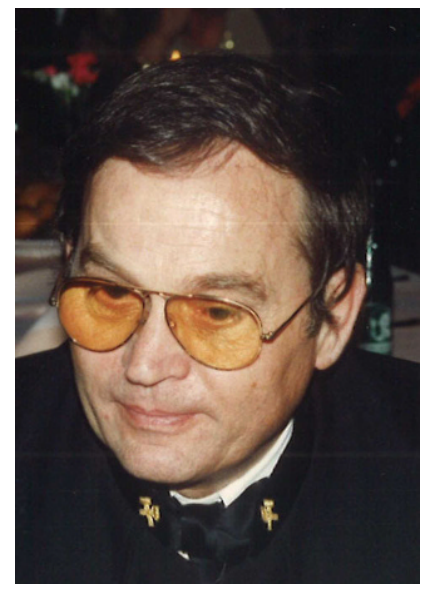

Am 18. September 2017 ist Univ.-Prof. Dipl.-Ing. Dr. mont. Richard Nötstaller im Alter von 76 Jahren verstorben.

1941 in Tragwein (Oberösterreich) geboren, hat Richard Nötstaller seine akademische Ausbildung an der Montanistischen Hochschule Leoben erfahren. Nach dem Abschluss des Studiums des Bergwesens 1968, seiner Promotion 1982 sowie der Habilitation 1989 war die Basis für seine anerkannte bergwirtschaftliche Expertise geschaffen. Beruflich war Nötstaller in der Erdöl- und Bergbauzulieferindustrie in Afrika, den USA und Großbritannien tätig. Im Jahr 1987 machte er sich schließlich selbständig und avancierte zu einem international renommierten Experten für Bergwirtschaft und Kleinbergbau in Entwicklungsländern. Die Weltbank, für die er zahlreiche Studien schrieb, vertraute jahrzehntelang auf seine Dienste.

Die Verbundenheit Nötstallers zu seiner Alma Mater Leobiensis blieb sein Leben lang bestehen. So war er über viele Jahre als Lehrbeauftragter und als Gastprofessor an der Montanuniversität tätig und bereicherte die Ausbildung vieler Studenten mit seinem Fachwissen und seinem beruflichen Erfahrungsschatz.

Auch im Bergmännischen Verband Österreichs war Richard Nötstaller über Jahrzehnte aktiv. Seine Tätigkeit im Fachausschuss für bergmännische Betriebswirtschaft, seine Funktion im Vorstand und im Vorstandsausschuss waren wegweisend für die Entwicklung des Verbandes.

Richard Nötstaller lebte und verstarb in Niederösterreich. Unser Mitgefühl gilt der Familie. Wir werden dem Verstorbenen ein ehrendes Andenken bewahren.

Ein letztes Glückauf!

Peter Moser 